\title{
Analysis of changes in the value of selected lubricant characteristics during use
}

\author{
Bogdan Landowski ${ }^{1, *}$, Monika Baran $^{1}$ \\ ${ }^{1}$ University of Science and Technology in Bydgoszcz, Faculty of Mechanical Engineering, Al. prof. \\ S. Kaliskiego 7, 85-796 Bydgoszcz, Poland
}

\begin{abstract}
The problems connected with assessment of value changes of selected lubricants during the operation are addressed in this study. The lubricants which have been analyzed are engine oils used in internal combustion drive units of transport means. Selected results of tests of engine oils used for lubrication of passenger car drive units have been presented. The values of kinematic viscosity were determined for different temperatures. In order to evaluate the impact of the oil operation in real working conditions on the viscosity parameters, oil samples were collected from selected vehicles. The vehicles had been used in natural conditions providing transport services. Measurements of kinematic viscosity were performed by means of a rotary viscometer.
\end{abstract}

\section{Introduction}

The basic function of lubricants is to provide the surfaces of elements that make up tribological nodes protection from excessive wear. Application of lubricants affects the processes of wear by reducing their intensity.

Lubrication oils are commonly used for lubrication of machine elements. Thanks to the so called lubricating film that is formed on the element surfaces the friction forces are reduced and the wear process is limited [1].

The authors of this study address the problems connected with assessment of value changes of selected characteristics of lubricants during their operation. Engine oils for combustion drive units used in transport means were chosen for analysis.

Engine oils make up the costs involved in transport means operation [2-3]. In the case of large lubricating systems and short time between the oil changes, the costs are of particular significance. As regards public bus transport systems the costs are very high [3-4]. Hence, the models of transport means operation processes often include the costs of lubricants [3-8]. The economic factors such as the type of lubricant to be used or frequency of its change are not considered in this study.

The function of oil is also to prevent impurities from depositing on the engine elements. Sludges (low temperature sludge), sealing waxes (high temperature residue) carbon deposits (thermal disintegration products) should be dissolved and distributed within the oil by dispersing-washing agents contained in the oil. Thanks to this, they should be removed from the engine upon changing the oil. Another function of the oil is to protect an engineering object from corrosion. The oil should not have a destructive impact on the drive unit sealing [9-12]. Hence, it is necessary to provide organoleptic assessment of the lubricated elements such as, oil sump or oil sucking pipe which can be useful for evaluation of oils used in real conditions of a drive unit operation.

Monitoring rheological parameters of oil can facilitate assessment of the engine elements potential damage. Reduction of the oil viscosity value can indicate content of fuel or coolant in it.

\footnotetext{
* Corresponding author: bogdan.landowski@utp.edu.pl
} 
The study presents an analysis of selected results of tests of engine oils used to lubricate drive units of passenger cars. The tests included selected engine oils with different viscosity classes according to SAE. Among others, their kinematic viscosity value was determined for different temperatures. Oil samples collected from selected vehicles were tested to provide assessment of the impact of oils used in real working conditions on viscosity parameters. The analyzed transport means were being used in real conditions and were providing transport services.

\section{Research methodology}

$1000 \mathrm{~cm}^{3}$ volume samples collected from drive units of the analyzed vehicles referred to as used oils have been tested. Samples of unused oil referred to as virgin oil have been tested as well.

Table 1. Data concerning used oils.

\begin{tabular}{|c|c|c|c|c|c|c|c|}
\hline \multirow[b]{3}{*}{$\begin{array}{c}\text { No } \\
\cdot\end{array}$} & \multirow{3}{*}{$\begin{array}{l}\text { OIL } \\
\text { SAE }\end{array}$} & \multicolumn{5}{|c|}{ CAR } & \multirow[b]{3}{*}{$\begin{array}{c}\text { Oilmileage } \\
{[\mathrm{km}]}\end{array}$} \\
\hline & & & & \multirow[b]{2}{*}{ Engine } & \multicolumn{2}{|c|}{ Mileage } & \\
\hline & & $\begin{array}{l}\text { Make } \\
\text { and } \\
\text { model }\end{array}$ & $\begin{array}{c}\text { Production } \\
- \\
\text { year }\end{array}$ & & $\begin{array}{l}\text { Upon } \\
\text { being } \\
\text { poured } \\
\text { into the } \\
\text { engine } \\
\text { [km] }\end{array}$ & $\begin{array}{c}\text { After } \\
\text { being } \\
\text { poured } \\
\text { down } \\
\text { from the } \\
\text { engine } \\
\text { [km] }\end{array}$ & \\
\hline 1. & $5 \mathrm{~W}-30$ & $\begin{array}{c}\text { VW } \\
\text { Tiguan }\end{array}$ & 2011 & $\begin{array}{l}1.4 \mathrm{TSI} \\
150 \mathrm{KM}\end{array}$ & 125000 & 139520 & 14520 \\
\hline 2. & $5 \mathrm{~W}-30$ & $\begin{array}{l}\text { Peugeot } \\
\text { Partner }\end{array}$ & 2003 & 2.0 HDi 90KM & 382670 & 403279 & 20609 \\
\hline 3. & $5 \mathrm{~W}-30$ & $\begin{array}{l}\text { Skoda } \\
\text { Yeti }\end{array}$ & 2010 & $\begin{array}{c}2.0 \\
\text { TDI, 170KM, } \\
\text { chip tuning up } \\
190 \mathrm{KM}\end{array}$ & 93458 & 109585 & 16127 \\
\hline 4. & $5 \mathrm{~W}-30$ & Mazda 3 & 2005 & $\begin{array}{c}1.6 \mathrm{CiTD} \\
109 \mathrm{KM}\end{array}$ & 258750 & 269695 & 10945 \\
\hline 5. & $0 \mathrm{~W}-40$ & $\begin{array}{c}\text { VW } \\
\text { Golf VI } \\
\end{array}$ & 2011 & $\begin{array}{l}1.4 \mathrm{TSI}, \\
122 \mathrm{KM} \\
\end{array}$ & 66000 & 73000 & 6000 \\
\hline 6. & $5 \mathrm{~W}-40$ & $\begin{array}{c}\text { Opel } \\
\text { Astra H }\end{array}$ & 2004 & $\begin{array}{c}1.6 \text { EcoTec } \\
105 \mathrm{KM}\end{array}$ & 37115 & 52375 & 15260 \\
\hline 7. & $10 \mathrm{~W}-40$ & Audi A4 & 1998 & $\begin{array}{l}1.9 \mathrm{TDI} \\
110 \mathrm{KM}\end{array}$ & 257420 & 269670 & 12250 \\
\hline
\end{tabular}

The oils were divided into two groups groups. The first group included oils of the same viscosity class though coming from different drive units and samples of virgin oil. In the second group there were oil samples of the same make and type (with the same trade mark). The second group included post-use oils and unused oils (virgin) of the same summer (later winter) viscosity class.

To collect a sample, the used oil with temperature of about $90^{\circ} \mathrm{C}$ was poured down from the engine to a vessel. It was carefully mixed and then a sample was taken. Seven samples of used oil were subjected to tests in a drive unit and four samples of unused oils were tested as well.

Each measurement of the analyzed quantities was repeated five times.

Table 1 shows selected characteristics of the vehicles from which the tested engine oil samples were collected. 
Kinetic viscosity measurement was performed by means of a rotary viscometer FUNGILAB. Viscosity measurement of each temperature was repeated five times, at 10 minute intervals, for each sample. The oil used for tests did not contain air bubbles and was stabilized.

The viscosity index was calculated on the basis of measurements according to the directives of PN-ISO 2909:2009 norm.

\section{Selected tests results}

The selected results of tests of the first oil group are presented in table 2 and in figures 1 and 2 [13-14].

Table 2 shows the values of the arithmetic mean of the kinematic viscosity measurement results and the determined values of viscosity index of oil denoted according to SAE 5W30 [13-14].

Figure 1 shows a comparison of kinematic viscosity of unused 5W-30 oil with used oils coming from different drive units in positive temperatures, whereas in figure 2 in negative temperatures [13-14]. Table 3 shows explanations of the oil sample code symbols whose test results are illustrated in figure 2.

In order to illustrate the considerations, figure 3 shows a photograph of a used contaminated oil from Peugeot Partner vehicle, whereas figure 4 shows paper chromatography of oil from Peugeot Partner car after 72 hours [13-14].

Table 2. Results of kinematic viscosity measurements and determined values of viscosity index - 5W30 oil.

\begin{tabular}{|c|c|c|c|c|c|}
\hline $\begin{array}{c}\text { Analyzed } \\
\text { characteristic }\end{array}$ & $\begin{array}{c}\text { Unused } \\
\text { oil }\end{array}$ & $\begin{array}{c}\text { VW } \\
\text { Tiguan }\end{array}$ & $\begin{array}{c}\text { Peugeot } \\
\text { Partner }\end{array}$ & $\begin{array}{c}\text { Skoda } \\
\text { Yeti }\end{array}$ & Mazda 3 \\
\hline $\begin{array}{c}\text { Kinematic } \\
\text { viscosity in } \\
\text { temperature } 21^{\circ} \mathrm{C}\end{array}$ & $\begin{array}{c}145.52 \\
\mathrm{~mm}^{2} / \mathrm{s}\end{array}$ & $\begin{array}{c}144.9 \\
\mathrm{~mm}^{2} / \mathrm{s}\end{array}$ & $\begin{array}{c}210.24 \\
\mathrm{~mm}^{2} / \mathrm{s}\end{array}$ & $\begin{array}{c}117.34 \\
\mathrm{~mm}^{2} / \mathrm{s}\end{array}$ & $\begin{array}{c}140.94 \\
\mathrm{~mm}^{2} / \mathrm{s}\end{array}$ \\
\hline $\begin{array}{c}\text { Kinematic } \\
\text { viscosity in } \\
\text { temperature 40 }\end{array}$ & $\begin{array}{c}65.42 \\
\mathrm{~mm}^{2} / \mathrm{s}\end{array}$ & $\begin{array}{c}62.68 \\
\mathrm{~mm}^{2} / \mathrm{s}\end{array}$ & $\begin{array}{c}88,38 \\
\mathrm{~mm}^{2} / \mathrm{s}\end{array}$ & $\begin{array}{c}51,46 \\
\mathrm{~mm}^{2} / \mathrm{s}\end{array}$ & $\begin{array}{c}56,02 \\
\mathrm{~mm}^{2} / \mathrm{s}\end{array}$ \\
\hline $\begin{array}{c}\text { Kinematic } \\
\text { viscosity in } \\
\text { temperature 100 }{ }^{\circ} \mathrm{C}\end{array}$ & $\begin{array}{c}11.24 \\
\mathrm{~mm}^{2} / \mathrm{s}\end{array}$ & $\begin{array}{c}11.14 \\
\mathrm{~mm}^{2} / \mathrm{s}\end{array}$ & $\begin{array}{c}15.6 \\
\mathrm{~mm}^{2} / \mathrm{s}\end{array}$ & $\begin{array}{c}10.2 \\
\mathrm{~mm}^{2} / \mathrm{s}\end{array}$ & $\begin{array}{c}11.02 \\
\mathrm{~mm}^{2} / \mathrm{s}\end{array}$ \\
\hline $\begin{array}{c}\text { Kinematic } \\
\text { viscosity in } \\
\text { negative }\end{array}$ & $\begin{array}{c}5055.98 \\
\mathrm{~mm}^{2} / \mathrm{s} \\
\text { temperature }\end{array}$ & $\begin{array}{c}5158.16 \\
\mathrm{~mm}^{2} / \mathrm{s} \\
-25^{\circ} \mathrm{C}\end{array}$ & $\begin{array}{c}7590.62 \\
\mathrm{~mm}^{2} / \mathrm{s} \\
-25^{\circ} \mathrm{C}\end{array}$ & $\begin{array}{c}4988.22 \\
\mathrm{~mm}^{2} / \mathrm{s} \\
-26\end{array}$ & $\begin{array}{c}5585.92 \\
\mathrm{~mm}^{2} / \mathrm{s} \\
-{ }^{\circ} \mathrm{C}\end{array}$ \\
\hline $\begin{array}{c}\text { Viscosity index } \\
\text { in positive } \\
\text { temperature }\end{array}$ & 166.03 & 172.29 & 188.46 & 190.98 & 193.34 \\
\hline
\end{tabular}




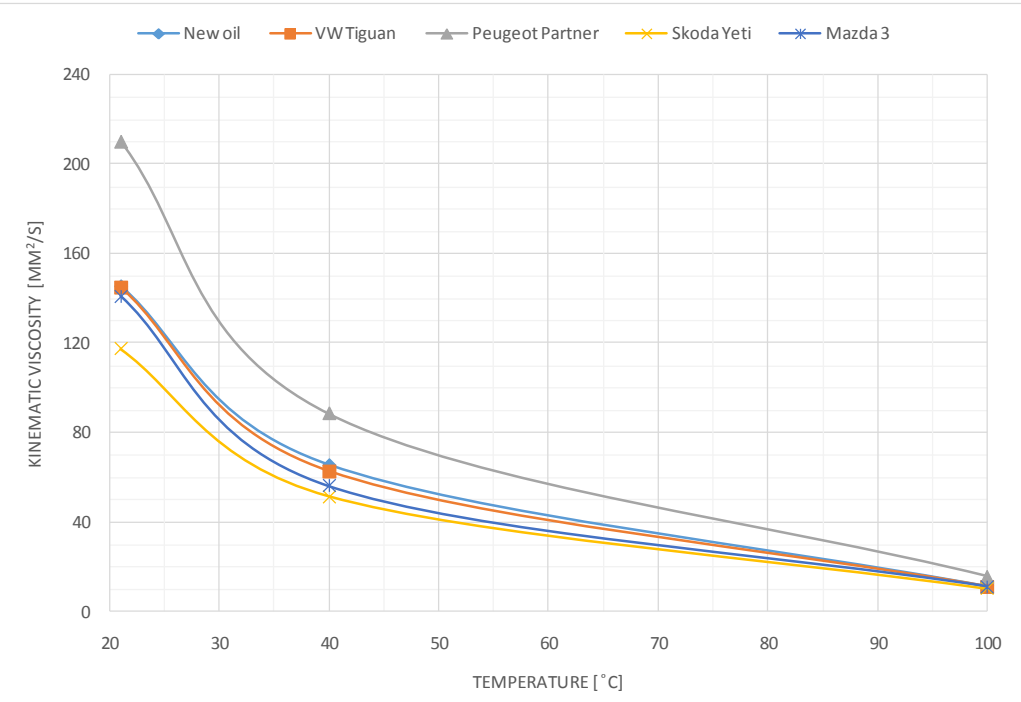

Fig. 1. Comparison of the values of kinematic viscosity of unused 5W-30 oil with used oils from different drive units in positive temperatures.

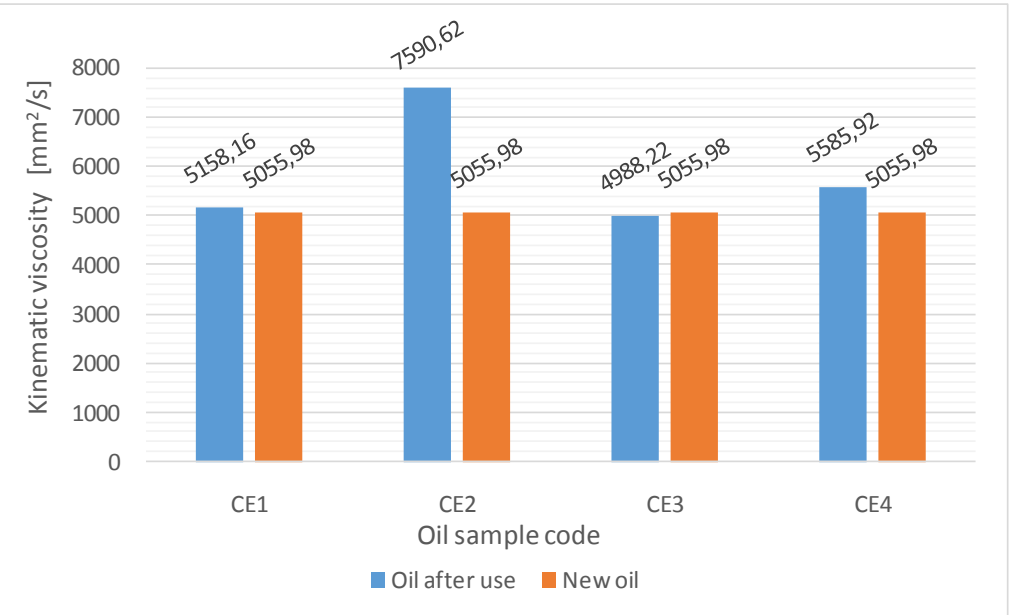

Fig. 2.Comparison of values of kinematic viscosity of unused 5W-30 oil with used oil from different drive units in negative temperatures.

Table 3. Code symbols of oil samples.

\begin{tabular}{|c|c|c|}
\hline Code & Explanation & $\begin{array}{c}\text { Temperature of } \\
\left.\text { sample [ }{ }^{\circ} \mathbf{C}\right]\end{array}$ \\
\hline CE1 & $5 \mathrm{~W}-30-$ VW Tiguan & -25 \\
\hline CE2 & $5 \mathrm{~W}-30-$ Peugeot Partner & -20 \\
\hline CE3 & $5 \mathrm{~W}-30-$ Skoda Yeti & -26 \\
\hline CE4 & $5 \mathrm{~W}-30-$ Mazda 3 & -30 \\
\hline- & $5 \mathrm{~W}-30-$ virgin oil (new oil) & -25 \\
\hline
\end{tabular}




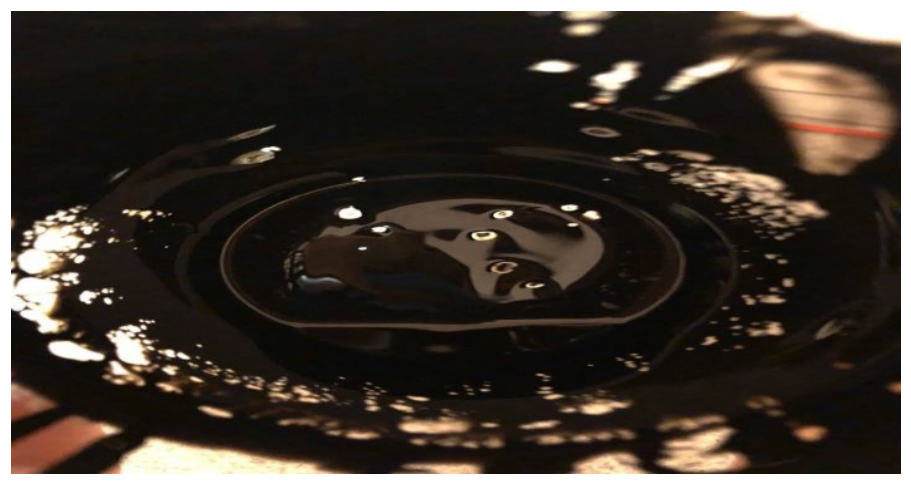

Fig. 3. Contaminated oil from Peugeot Partner [14].

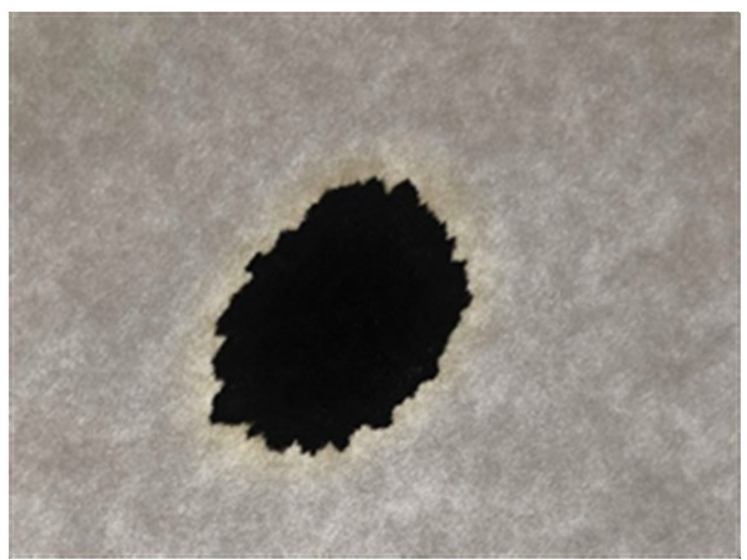

Fig. 4. Paper chromatography of oil from Peugeot Partner after 72 hours [14].

Selected results from tests of the second group of the analyzed oils are presented in table 4 and in figures 5 and 6.

An analysis of the diagram presented in figure 5 shows that the determined characteristics of oils are similar. Differences between viscosity values of oils decrease along with the temperature increase for all the analyzed temperatures.

Table 4. Mean values from kinematic viscosity test results and determined values of viscosity index.

\begin{tabular}{|c|c|c|c|}
\hline Tested characteristic & $\begin{array}{c}\text { Result of } \\
\text { measurement for } \\
\mathbf{0 W - 4 0} \text { oil }\end{array}$ & $\begin{array}{c}\text { Result of } \\
\text { measurement for } \\
\mathbf{5 W - 4 0 ~ o i l ~}\end{array}$ & $\begin{array}{c}\text { Result of } \\
\text { measurement for } \\
\mathbf{1 0 W - 4 0 ~ o i l ~}\end{array}$ \\
\hline $\begin{array}{c}\text { Kinematic viscosity in } \\
\text { temperature } 21^{\circ} \mathrm{C}\end{array}$ & $149.9 \mathrm{~mm}^{2} / \mathrm{s}$ & $174.86 \mathrm{~mm}^{2} / \mathrm{s}$ & $228.22 \mathrm{~mm}^{2} / \mathrm{s}$ \\
\hline $\begin{array}{c}\text { Kinematic viscosity in } \\
\text { temperature } 40^{\circ} \mathrm{C}\end{array}$ & $66.12 \mathrm{~mm}^{2} / \mathrm{s}$ & $75,38 \mathrm{~mm}^{2} / \mathrm{s}$ & $94.98 \mathrm{~mm}^{2} / \mathrm{s}$ \\
\hline $\begin{array}{c}\text { Kinematic viscosity in } \\
\text { temperature } 100^{\circ} \mathrm{C}\end{array}$ & $12.1 \mathrm{~mm}^{2} / \mathrm{s}$ & $12.58 \mathrm{~mm}^{2} / \mathrm{s}$ & $13.68 \mathrm{~mm}^{2} / \mathrm{s}$ \\
\hline $\begin{array}{c}\text { Viscosity index in } \\
\text { negative temperature }\end{array}$ & $3968.68 \mathrm{~mm}^{2} / \mathrm{s}$ & $5015.78 \mathrm{~mm}^{2} / \mathrm{s}$ & $6200.21 \mathrm{~mm}^{2} / \mathrm{s}$ \\
$-25^{\circ} \mathrm{C}$ & 166.03 & 166.7 & 145.65 \\
\hline $\begin{array}{c}\text { Viscosity index in } \\
\text { positive temperature }\end{array}$ & \multicolumn{2}{|c}{$\mathrm{C}^{\circ}$} \\
\hline
\end{tabular}




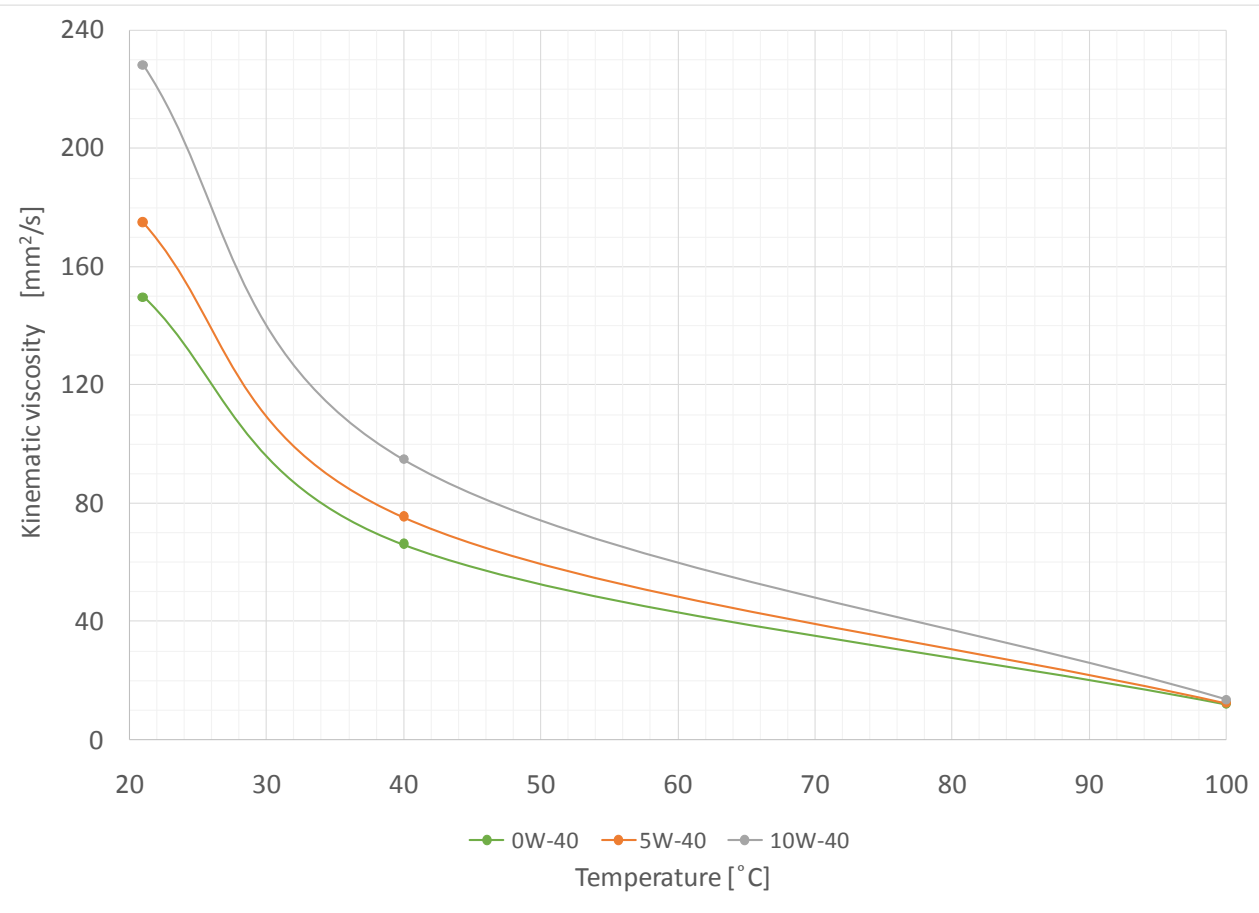

Fig. 5. Comparison of kinematic viscosity value for virgin oils from the analyzed group of oils.

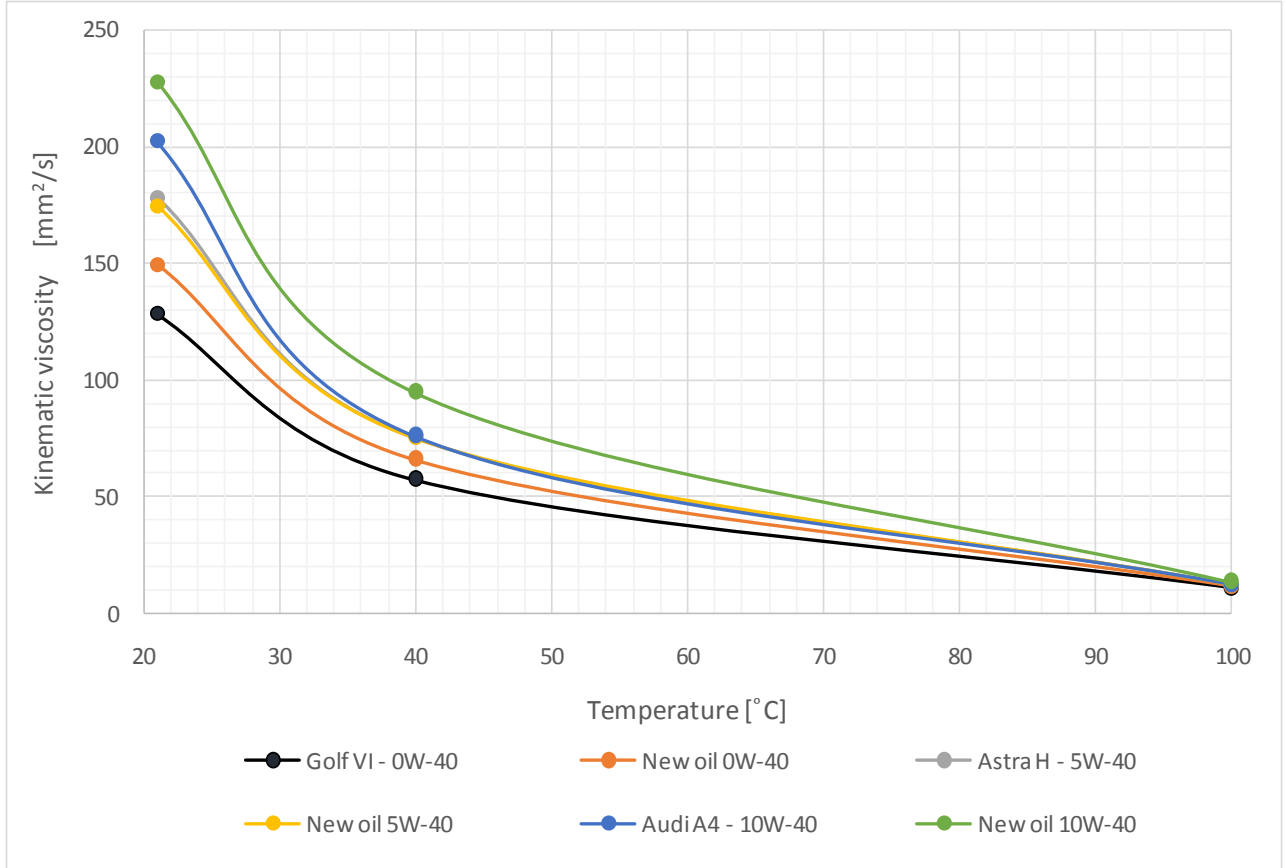

Fig. 6. Values of kinematic viscosity of oils with viscosity symbols according to SAE, respectively, $0 \mathrm{~W}-40,5 \mathrm{~W}-40$ and $10 \mathrm{~W}-40$ unused and used in drive units of the analyzed vehicles. 


\section{Conclusions}

The test results presented in this study are supposed to provide assessment of the impact of engine oil application on value changes of selected characteristics of lubricants.

Basing on the result analysis it can be observed that kinetic viscosity value of the same type of oils can differ depending on the operation time and the drive unit they have been used in.

The highest values of kinematic viscosity for all tested temperatures were found for the oil from Peugeot Partner vehicle.

The dependence of the kinematic viscosity value on temperature has similar nonlinear characteristics for both used and unused oils. The differences between measurement results for virgin and used oils are lower in higher temperatures regardless of their viscosity class, and they increase along with the temperature drop for all tested temperatures.

An analysis of the test results allows to state that the highest increase in the oil kinematic viscosity of the used oil as compared to the virgin oil was found for $5 \mathrm{~W}-30$ oil from Peugeot Partner vehicle. It can be caused by impurities that are present in the engine in the form of sealing waxes and residues which were found by means of organoleptic assessment of the engine parts.

\section{References}

1. W. Zwierzycki, Fuels, Oils, Motor opertional liquids. Oil Refinery 'Glimar' S.A. Editorial Office in Gorlice, Gorlice (1998)

2. B. Landowski, Ł. Muślewski, M. Pająk, O. Polishchuk, Method for initial assessment of unit costs of public city transport means operation, MATEC Web of Conferences 182, 01010 (2018), 17th International Conference Diagnostics of Machines and Vehicles, pp.1-7 (2018), https://doi.org/10.1051/matecconf/201818201010

3. B. Landowski, D. Perczyński, Ł. Muślewski, P. Kolber, Economic aspects of a city transport means purchase. Proceedings of 58th International Conference of Machine Design Departments - ICMD 2017, Publisher: Czech University of Life Sciences Prague, Czech Republic, pp. 194-199 (2017)

4. B. Landowski, Ł. Muślewski, Decision model of an operation and maintenance process of city buses, Proceedings of 58th International Conference of Machine Design Departments - ICMD 2017, Publisher: Czech University of Life Sciences Prague, Czech Republic, pp. 188-193 (2017)

5. B. Landowski, Numerical simulation of the process of a technical object state changes. Journal of KONBiN 45(2018), pp. 247-266 (2018)

6. B. Landowski, D. Perczyński, P. Kolber, Ł. Muślewski, An example of Markov model of technical objects maintenance process. Engineering Mechanics 2016, 22nd International Conference, may 9 - 12, 2016, Svratka, Czech Republic, Book of full texts, Institute of Thermomechanics Academy of Sciences of the Czech Republic, pp. 346-349 (2016)

7. B. Landowski, Ł. Muślewski, Numerical simulation of stochastic process as a model of technical object state changes. Engineering Mechanics 2018, 24nd International Conference, may 14 - 17, 2018, Svratka, Czech Republic, Book of full texts, Institute of Theoretical and Appiled Mechanics of the Czech Academy of Sciences, Prague, pp. 485-488 (2018)

8. B. Landowski, Numerical simulation of the process of a technical object state changes. Journal of KONBiN 44(2017), pp. 119-140 (2017)

9. A. Ambrozik, J. Jakóbiec, G. Wysopal, Basic tendencies in motor lubricant changes. Buses: technology, operation, transport systems, No. 12 (2011)

10. K. Hoag, B. Dondlinger, Engine Lubrication. Vienna (2015), DOI 10,1007/978-37091-1859-7_12 
11. A. M. Ryniewicz, Ł. Bojko, T.Madej, Assessment of motor oil viscosity with the use of rotary viscometer, Scientific bulletins of Silesian University of Technology, Transport, Vol. 83, No. 1904 (2014)

12. W. Urzędowska, Z. Stępień, Selectes issues concerning motor lubricant viscosity changes during operation. NAFTA-GAZ, December, Poland (2012)

13. B. Landowski, M. Baran, Analysis of viscosity of selected motor lubricants. University of Science and Technology materials, Department of Maintenance and Transport, Bydgoszcz, Poland (2019)

14. M. Baran, Analysis of selected characteristics of engine oils. Diploma thesis, University of Science and Technology, Bydgoszcz, Poland (2019) 